\title{
Using Project-based Learning in Writing an Educational Article: An Experience Report
}

\author{
Aceng Hasani $^{1{ }^{* *},}$ Aan Hendrayana ${ }^{2}$, Arip Senjaya ${ }^{1}$ \\ ${ }^{1}$ Department of Language Education, Faculty of Education and Teaching Sciences, Sultan Ageng Tirtayasa University, Indonesia \\ ${ }^{2}$ Department of Mathematics Education, Faculty of Education and Teaching Sciences, Sultan Ageng Tirtayasa University, Indonesia
}

Copyright $\mathrm{O} 2017$ by authors, all rights reserved. Authors agree that this article remains permanently open access under the terms of the Creative Commons Attribution License 4.0 International License

\begin{abstract}
Writing skills of students in various faculties are competencies that need to be developed in accordance with the vision and purpose for the faculty itself. The Faculty of Education is a faculty which educates and writing skills to students from any department to have a sensitivity and a critical attitude toward education. This research employs qualitative research. It was expected to give inspirations to further research in linear field and also to inspire readers to implement writing based-project in their instruction. Using project-based learning directly guides them to write an article. The study involved 32 students of the 2nd of Mathematics Education Academic Year 2015/2016. We describe a reflective study on their articles that published in the local mass media. The results show that the students' interest were very varied, there are education and history education, education and values, contemporary problems of education and mathematics education. It is also show that using project based-learning, the number of students' articles published in mass media is $25 \%$ ( 8 of 32 articles), the remain articles $(75 \%)$ were under review. From the results, it can be concluded that by using project-based learning, students' writing ability can be enhanced. Further, this learning can foster student learning and engage faculty in professional development.
\end{abstract}

Keywords Writing, Project Based Learning, Mass Media Article

\section{Introduction}

Writing is necessary for learning. From Baines' perspectives, it is incredible to consider that writing has not always been an integral part of the curriculum [1]. For this reason, students aware that they did not feel to have this field as an integral part of their discipline. Their presence in the class is often caused by mere awareness of institutional leaders or lecturers that students need to have the ability to standards in reporting task. Therefore, writing is taught in technical areas without ever referring to the purpose of the study program that inherent with the institution's vision. Writing learning in the study program must inherent with a goal of the study program. So that, writing learning is not emphasized on theories of writing, but on writing task.

Each study program is managed by the faculty overriding so that each study program must have a common goal of writing learning with another program in the same faculty. It is not true that each writing course has the same contents. This perspective caused by the vision of each faculty is not integrated into writing course. Each of faculty has the writing topic that different with others. Writing topic has the same purpose if it did in the same faculty. Therefore, the goal of writing for students Faculty of Education of any study program must contain the same purpose and passion. There is no different writing goal for students of mathematics education with students of language education. Therefore, it is necessary for each study program to develop writing in order to increase students' skill. Whatever study program, writing standards for the faculty of education must bear the hallmark of education.

\section{Theoretical Framework}

We choose the definition of writing below.

Writing is a complex, multifaceted, and purposeful act of communication that is accomplished in a variety of environments, under various constraints of time, and with a variety of language resources and technological tools [2].

Until now, the definition of writing above has not been changed by the National Council Assessment of the United States. The framework of the definition is built with a new awareness on what is writing. This awareness should also be a part of awareness of other countries, including Indonesia, that cannot be avoided limited time, busyness increases, expanding social networks, breadth of information which can be obtained as a result of the widespread culture of information technology results in writing as an activity also 
be subject the paradigm of information technology in this global network. Technology tools in question refer to the writing system based on information technology. This understanding is useful for us because we use technology as well as purposeful manner.

In [3], Indonesia is the country which has to experience social changes caused by the ability people in writing. The growing religions in this country, the entry of modernization, gained independence, a maturity of society at the beginning of independence, struggle to equalize themselves in Asian and association in the world, never apart of the ability of fighters in writing. Therefore, if the writing ability is low, students are not possible to outdistance their predecessors. Unlike his predecessors which grew into the nation builders from the tradition of literacy print-based literacy, students now running the activity mix and even more interaction with digital literacy. Therefore, education experts to develop education based on the web in order to keep abreast of the times. The presence of internet information technology is an opportunity for students was to fulfill the desire of the project (Lecturer itself, or in the particular institution) the search for information. On the other hand, the giver of the project also can receive feedback which opens the possibility of improvement for both parties. This model has grown old in the education system one of which was recorded in the Quadrille System (Figure 1).

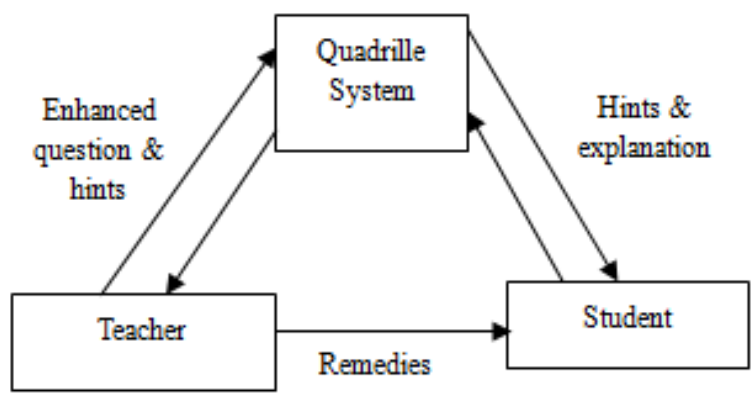

Figure 1. Education Quadrille System [4]

According to instructions that appear on the chart above may be only possible if the recipient of the project produces work that is open (student performance data). Open creation is a work that can be addressed with questions that sharpen the achievement of works. This is one of the advantages learning to write project-based, both the giver project, as well as project recipients, can enhance each other. Giver project can find the results of student work as a point of departure to enhance student jobs(remedies) and along with it enhance the lecturer questions anyway(enhanced question \& hints).

Lecturers can utilize world students as a source of learning to write. Task lecturer no more than guides: not all students reading sources can support the objectives. Writes project-based only required readings which support the project.

A method of writing project-based obviously a derivative from project-based learning that first evolved in Europe which is a response the lack of contextualization, simplification, and abstraction excessive in the classroom [5]. Proulx (2004) stated that project-based learning as a learning based objective, given nature which controls learners in particular purpose. Explained classical theoretical project-based learning

Project-based learning is based learning on the goals, among other things:

- introduce learners to some methods of collecting data needed to write;

- develop learners in a progressive approach in writing;

- enable learners to effectively read data which supports the writing;

- develop learners in terms of imagination and creativity, and skills to build logical scenario in a way comparing data;

- learn to a scenario in, etc.

Proulx, (2004) explained that lecturers can continue the results of project-based learning the more advanced he called "Helpful reverie" (reverie bienfaisante) Innumerable, etc. Student workshop has saved the lecturers from the chaos of their own understanding students' writing and save students from the tradition of literacy is not good, can be forwarded the original project is a daydream: imagine students become productive intellectuals and widely known way to include these works, all or some of the best, in the competition of scientific work at the local level, national, and even the world.

The Proulx theory above factually still applies today. Altogether he was not left behind by the changes. For mere comparison, we can see a number of the following opinion.

(1) Bell (Valls-Barreda, 2016: 31):

Project-Based Learning (PBL) is an innovative approach to learning that teaches a multitude of strategies critical for success in the twenty-first century... PBL is a student-driven, teacher-facilitated approach to learning.... PBL is a key strategy for creating independent thinkers and learners.

(2) Holm (Valls-Barreda, 2016: 31)

Project-based learning can be described as student-centered instruction that occurs over an extended time period, during which students select, plan, investigate and produce a product, presentation or performance that answers a real-world question or responds to an authentic challenge. Teachers generally serve as facilitators, providing scaffolding, guidance and strategic instruction as the process unfolds.

If we combine Proulx's arguments with Bell's opinion, the most important differentiator in the opinion of Bell is project-based learning is a strategy to create thinker and learners who have the independence. Meanwhile, according to Holm, focused methods learner can conduct students in the real world and train students to be responsive; and lecturer in the opinion of Holm is a facilitator who directed 
them to the goals they want to achieve.

We use the project-based learning stages of Chamberland, Lavoie, and Marquis. The stages as shown in the following chart (Figure 2).

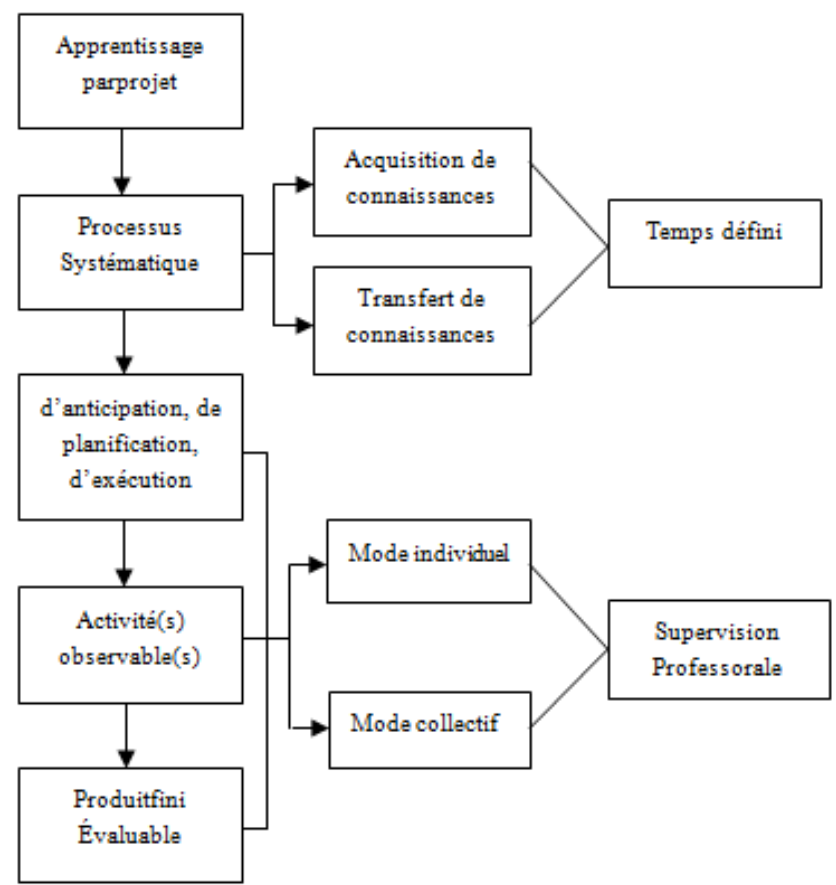

Figure 2. Project-Based Learning Stages of Chamberland, Lavoie, And Marquis [6].

Based on the chart Chamberland et al. above, every individual in the classroom treated as individuals with the knowledge different so that the lecturer gives great opportunities on any interest in knowledge. No one student views will be the theme of the project more superior to others. Any interest in knowledge is capital projects for each student. Once a student believes his interest could deliver them at each selection, lecturers helped prepare a framework of article writing in the systematics article. Not all student understands ways of writing a title, a technique to begin writing an article, paragraph development, how to close the paper well. This stage has also accompanied a step of administering the provision of anticipation on sources that will not benefit students. Lecturers provide knowledge on a good resource. They introduced with the names of local and national mass media they can read, and they were given the understanding about the many sites on the internet that is not necessarily well as a source. Once they get the resources to guarantee them, lecturer observes and responds preparation for writing the article. Are the ingredients sufficient? Does the plan have the relevant title the interests of each student? The titles that do not have the characteristics an article soon rectified before they arrived at the stage of writing articles as the final product of the project. Please note by lecturers that at the stage debriefing anticipation and the provision of capital planning, lecturer implicitly should have directed them the acquisition of the final product as product knowledge which can be channeled (Acquisition de reconnaissance) and become part of the transfer of knowledge for the public (transfer de reconnaissance). This stage is accompanied also by building awareness of students' limitations on time: lecturers prepare deadline for each stage (temps definition). This is equal to defined spirit writing Framework of 2011. At this stage of explanation insight about systematics article, lecturers must not impose a standard formula as a form of collective agreed (individual mode) but also have to appreciate the writing style each individual (collective mode).The final stage, after the deadline, cannot be changed anymore, lecturers to supervise and advise publication of articles to media the selected lecturer as supervision professional.

\section{Methods}

This research employs qualitative research. Qualitative research has an advantage to let researcher get better inspiration. Further, Lincoln and Guba state that qualitative method is a method which is giving a revelation (its ability to be revelatory) [8]. This research was expected to give inspirations to further research in linear field and also to inspire readers to implement writing based-project in their instruction.

The stages of this research were based on Proulx stages which are described in section 2. The first stage is supervising students to collect suitable data. The second is increasing students' progressivity in developing their article that already written. The third is guiding student in developing a logical scenario and ability to compare the research data. The last stage is stimulating students to engage in cooperative work or togetherness by engaging them to make an evaluation to other students' works and do correction or brainstorming. There are thirty-two students who participate in this research. The students were the first years of mathematics education students.

\section{Result and Discussion}

According to the data, there are several aspects of this instructional experience. The first, the articles had published create a psychological environment to students' in the sense of students' engaging with external campus environment. The second, for students, writing must be an integral part of the objective of the university. The third, writing based-project instruction, drive the students perspective when dealing with a problem and not only to improve writing ability theoretically. The last, writing not only considered as a subject study to pass away without getting writing competencies.

The number of students' articles published in mass media is $25 \%$ ( 8 of 32 articles). The rest articles $(75 \%)$ were under review. This data input is limited to the date of July 2, 2016 (see Table 1). Other articles may be issued after the date of July 2, 2016. 
Table 1. Students' Published Articles

\begin{tabular}{|c|c|c|c|c|}
\hline No. & Students & Title & Sections / Newspapers & Publishing date \\
\hline 1. & Student 1 & "Kembali ke Ajaran Ki Hadjar Dewantara" & "Opini”/KabarBanten & May 30, 2016 \\
\hline 2. & Student 2 & "Masih Adakah Pendidikan Moral" & “Opini"/Kadar Banten & May 31,2016 \\
\hline 3. & Student 3 & "Nyalakan Lilin dan Berhentilah Mengutuk Kegelapan" & "Wacana"/Warta Banten & May 31, 2016 \\
\hline 4. & Student 4 & "Lolos dari Fobia Matematika" & "Opini"/Kadar Banten & June 1,2016 \\
\hline 5. & Student 5 & “Apa Kabar Kurikulum 2013?” & “Opini”/KabarBanten & June 2, 2016 \\
\hline 6. & Student 6 & "Si Miskin Ingin Sekolah" & $\begin{array}{c}\text { "WacanaPublik"/Radar } \\
\text { Banten }\end{array}$ & June 3, 2016 \\
\hline 7. & Student 7 & "Ujian Nasional Hanya Formalitas" & "Nasional"/SinarPagi & June 5, 2016 \\
\hline 8. & Student 8 & "Problematika Pendidikan Tinggi" & $\begin{array}{c}\text { "WacanaPublik"/Radar } \\
\text { Banten }\end{array}$ & June 8, 2016 \\
\hline
\end{tabular}

According to the table above, it can be seen clearly that the students' interest were very varied. Education and history education (1); education and values $(2,3,6)$; contemporary problems of education $(5,7,8)$; and mathematics education (4). Table 1 above is representing students' writing achievement as an act of public communication. This achievement also represents the increasing of the students' engaging with society. This fact proved that project-based learning makes students think out of their discipline (mathematics education). From eight published articles, there is only one article that concern with mathematics topics (number 4). However, when examined again seven other writings, students use their mathematical thinking implicitly to construct their ideas. These findings reinforce research that has been done before by Boaler (1998) and his opinion [10]) stating that the project-based learning can be a trigger for learners in the use of multiple intelligent.

Further, the writing contents of all published article were criticizing the social problem in educational aspect. The article "Kembali ke Ajaran Ki Hadjar Dewantara" is criticism of the unclear direction of education in Indonesia, this is important for students of the faculty of education. "Masih Adakah Pendidikan Moral" is a critique of the many news that violates the moral, which is one of the important tasks prospective teacher and also as an exercise social control.

"Nyalakan Lilin dan Berhentilah Mengutuk Kegelapan" is the criticism of many who protest without a solution, it indicates the author began to think of anything more important than protests. "Lolos dari Fobia Matematika" is criticism of the low mathematics achievement nationally, which is a fundamental part of the field of science. "Apa Kabar Kurikulum 2013?" is a critique of loneliness news implementations curriculum in 2013 after the magnitude of the training budget that has been issued. "Si Miskin Ingin Sekolah" is a critique of the many people poor who cannot school; "Ujian Nasional Hanya Formalitas" is criticism over the lack of clarity competency criteria for students after graduating from a national exam; "Problematika Pendidikan Tinggi" is criticism of the high unemployment students after college graduation. This is in line with the opinion [11] which states that the ability to think critically concerned with the understanding of contextual author. Writing without mastery social context, context of the times, the context of the historical development science author, environmental context (See the definition of writing according to NAEP), is writing without insight.

Writing is the way to express the idea according to the author knowledge. Students of educational faculty have sufficient knowledge about education. By writing, students can exercise their writing ability according to their interest in educational themes. Therefore, their conception about education can increase significantly.

According to those topics above, students of educational faculty can create articles related to education. Rus (2016) stated that writing tasks requiring students to produce types of texts which are specific to the profession are likely to be successful, as they create and maintain motivation. And so, the characteristics of the students are important when assigning writing tasks. At the same time, the paper suggests some activities, strategies and methods which a language instructor may use during the class for an adequate achievement of teaching objectives for a lesson focused on the development of writing skills.

Project-Based-Learning (PBL) can be implemented to organize learning around projects [13]. This teaching approach considers constructive learning theories [14], where learners become active constructors of their knowledge. Students exploit PBL to cooperate in solving real problems and accomplishing tasks typical for world of work. It is easy to follow that PBL requires high student involvement. Producing an artifact that is of interest since others can use or view it represents a very motivating factor. It is recognized that motivation can do the difference between success and failure of a learning experience more than any other factor. In this scenario, the lecturer has a less central role and students result to be responsible for their own learning (learner-center education, while learning is the result of their interaction (learner-learner interaction).

The implementation of project-based learning forces students to think reflective. This learning gives big opportunity to students and lecture to communicate each other to create an article. Allan and Driscoll (2014) argued that integrating reflection into existing assignments has three 
potential benefits: enhancing assessment of learning outcomes, fostering student learning, and engaging faculty in professional development [15].

\section{Conclusions}

It is necessary for each study program to develop writing in order to increase students' skill. Whatever study program, writing standards for the faculty of education must bear the hallmark of education. One of learning strategies for developing writing skill is project-based learning. This strategy forces students to do reflective thinking that useful for enhancing students' competencies. In addition, this strategy emphasizes on writing an article practically under lecture's supervision. So, every student can create an academic article in the end of learning program.

Based on this experience research, we can conclude about the following. (1) The articles had published create a psychological environment to students' in the sense of students' engaging with external campus environment. (2) Writing in universities should be an integral part of the purpose of each faculty. (3) Writing based-project instruction, drive the students' perspective when dealing with a problem and not only to improve writing ability theoretically. (4) Writing is no longer seen as a subject to be followed, but also to get writing competencies.

\section{REFERENCES}

[1] L. Baines, "Project-Based Writing in Science," in Bold Visions in Educational Research, Rotterdam: Sense Publishers, 2014, pp. 1-18.

[2] NCES, "WRITING 2011: NATIONAL ASSESSMENT OF EDUCATIONAL PROGRESS AT GRADES 8 AND 12," 2011.

[3] P. Lowenberg, "Writing and Literacy in Indonesia," Stud. Linguist. Sci., vol. 30, no. 1, 2000
[4] C. K. Wong, W. W, and Y. C.H., "'Learning Through Web-Based Assessment', Web-based Learning: Men \& Machines," in Proceedings of The First International Conference on Web-based Learning in China, 2002, pp. 4858 .

[5] C. Garcíaa, "Project-based learning in virtual groups collaboration and learning outcomes in a virtual training course for teachers," Procedia - Soc. Behav. Sci., vol. 1, pp. 100-105, 2016.

[6] J. Proulx, Apprentissage par projet. Québec: Presses de l'Université du Québec, 2004.

[7] S. Valls-Barreda, "Analysis of Project Based Learning in a Digital Environment at a Networked High Schoo," J. Educ. Teach. Trainers, vol. 7, no. 1, pp. 27-49, 2016.

[8] K. G. Corley, "Seeking Qualitative Rigor in Inductive Research: Notes on the Gioia Methodology," Organ. Res. Method, vol. 16, no. 1, pp. 15-31, 2013.

[9] J. Boaler, "Open and closed mathematics: Student experiences and understandings," J. Res. Math. Educ., vol. 29, no. 1, pp. 41-62, 1998.

[10] H. Gardner, Multiple intelligences: The theory in practice. New York: Basic Books, 1993.

[11] A. Hasani, "Enhancing argumentative writing skill through contextual teaching and learning," Educ. Res. Rev., vol. 11, no. 16 , pp. 1573-1578, 2016.

[12] D. Rus, "A Didactic Approach to Writing Skills in a Technical Learning Environment," Procedia Technol., vol. 22, no. 2016, pp. 1191-196, 2016.

[13] P. C. Blumenfeld, E. Soloway, R. W. Marx, J. S. Krajcik, M. Guzdial, and A. Palincsar, "Motivating Project-based Learning: Sustaining the doing, supporting the learning," Educ.Psychol, vol. 26, no. 3-4, pp. 369-398, 1991.

[14] J. R. Savery and T. M. . Duffy, "Problem based learning: an instructional model and its constructivist framework," Educ. Technol, vol. 35, no. 5, pp. 31-38, 1995.

[15] E. G. Allan and D. L. Driscoll, "The three-fold benefit of reflective writing: Improving program assessment, student learning, and faculty professional development," Assess. Writ., vol. 21, no. 2014, pp. 37-55, 2014. 